\title{
Splenic Changes in Heart Surgery with Circular Circulation
}

\author{
Edmo Atique Gabriel, Camila Alcalde Mazza and Marina Alves Jacintho de Mello* \\ Union of the Colleges of the Great Lakes- UNILAGO, Brazil
}

${ }^{\star}$ Corresponding Author: Marina Alves Jacintho de Mello, Union of the Colleges of the Great Lakes- UNILAGO, Brazil; E-mail: marinajmello@hotmail.com

Received: March 04, 2020; Accepted: March 09, 2020; Published: April 12, 2020

\section{Summary}

Cardiac surgery-related morbidity and mortality may be higher in patients with malignant neoplastic disease. Inflammatory phenomena and immunological alterations secondary to the use of cardiopulmonary bypass may also increase tumor recurrence. The aging population favors the early diagnosis of cancer and new therapies that increase the survival of patients with malignant neoplasms. emergence of cancer patients who at the same time have a cardiomyopathy that requires surgery. The benefits, especially in terms of long-term survival and risks, have not yet been clearly established. This study evaluated the characteristics of cancer patients undergoing cardiac surgery with Cardiopulmonary Bypass (CPB) indicated for a different cause of the tumor: type of procedure required, morbidity and mortality, long-term survival and incidence of tumor recurrence. To carry out this study, we used bibliographic research, performing a review on the topic.

Keywords: Cardiac surgery, Extracorporeal circulation, Splenic changes

\section{Introduction}

Controversy over the appropriateness of cardiac surgery in cancer patients, especially if they are not in complete remission, is increasing in daily clinical practice. As there are no objective reasons to justify higher mortality in these patients, the interest of the procedure focuses on the prospects for long-term survival and the risks arising from the use of CPB through direct alteration of the immune system, may exacerbate the tumor and favor dissemination and / or relapse [1]. Since the 1990s, studies on cancer patients undergoing cardiac surgery have been published. Some exclude newly diagnosed or untreated cancers and others refer exclusively to the association of cardiac surgery and the simultaneous or deferred surgical excision of lung tumors. A third group describes the results of surgical treatment of cancers that affect the heart as a primary tumor or metastasis and require CPB for resection [2]. Finally, a final group includes patients affected by tumors with special characteristics, such as hematologic malignancies. The publications are few and far between and the series are limited and heterogeneous due to the low number of operated patients. The risk of selection bias is difficult to avoid and, in addition, the different origins, stages and degrees of tumor differentiation and spread make it difficult to compare results [3]. Although clinical treatment of heart disease progresses from year to year and the less invasive approach is expanding rapidly, cardiac surgery is the preferred intervention in some cases of heart disease [4]. Therefore, this study deals with cardiopulmonary bypass and cardiac surgery, considering the main theoretical findings on the subject.

\section{Cardiopulmonary Bypass}

Supportive cardiopulmonary bypass during cardiac surgery is unique because blood exposed to foreign surfaces of nonendothelial cells is collected and continuously recirculated throughout the body. This contact with synthetic surfaces within the perfusion circuit, as well as open tissue surfaces within the wound, trigger a defensive reaction involving at least five plasma protein systems and five circulating blood cell types [5]. This inflammatory response to cardiopulmonary bypass initiates a powerful thrombotic stimulus and the production, release, and circulation of vasoactive and cytotoxic substances that affect all organs and tissues of the body. Because of this, open-heart surgery using cardiopulmonary bypass is not possible without anticoagulation, which is usually with heparin; thus, the inflammatory response to cardiopulmonary bypass involves the consequences of exposure of heparinized blood to foreign surfaces uncoated with endothelial cells [6]. During Cardiopulmonary Bypass (CPB) for cardiac surgery, blood is typically severely drained into the venous reservoir of the heart-lung machine through cannulae placed in the superior and inferior vena cava or a single cannula placed in the right atrium. Specialized cannulae can also be placed in the inferior vena cava through a femoral approach [7].

The blood from the reservoir is then pumped through a hollow fiber oxygenator after appropriate gas exchange that occurs in the systemic arterial system through a cannula placed in the distal ascending aorta, femoral artery or axillary artery. This basic extracorporeal perfusion system can be adapted to provide partial or full circulatory and respiratory support or partial support for the left or right heart or lungs separately [8]. That is, Cardiopulmonary Bypass ( $\mathrm{CPB}$ ) is used to maintain the patient's blood circulation and / or pulmonary function outside the body. Oxygen-depleted blood is diverted out of the body and enriched with oxygen, passing it through an artificial lung (oxygenator) before being pumped back into the patient's circulation for up to six hours [9]. 


\section{Results Analysis and Discussion}

\section{Heart Disease And Cardiopulmonary Bypass (CPB)}

In order to perform different types of cardiac surgeries, Cardiopulmonary Bypass (CPB) remains a frequent procedure, aiming to provide a clean surgical field, preserve the functional characteristics of the heart and provide safety to the surgical team [10]. Cardiopulmonary Bypass (CPB) is a form of circulation in which the patient's blood is diverted from the heart and lungs out of the body. The normal physiological functions of the heart and lungs, including blood circulation, oxygenation and ventilation, are temporarily taken over by the ECC machine [7,11]. In most cases, the heart is also separated from the circulation (eg, aortic clamping) and the cardioplegia solution is administered to allow the cardiac surgeon to operate on a heart not beating in a bloodless field while other end organs they are adequately oxygenated and perfused [12].

\section{General Principles}

\section{Equipment and Physiology}

$\mathrm{CPB}$ components include pumps, tubing, and gas exchange (oxygenator) and heat exchange units. Modern $\mathrm{CPB}$ machines are also equipped with systems that continuously monitor line or circuit pressure, temperature and blood parameters (eg, oxygen saturation, blood gases, hemoglobin [Hgb], potassium) as well as safety features such as air and fluid level detection. Systems and a blood filter in the arterial line $[10,12,13]$. During cardiopulmonary bypass, venous blood is drained from the right atrium and is diverted through the venous line of the CPB circuit to a venous reservoir [14]. CPB machines are typically equipped with vacuum assisted technology that facilitates drainage to maintain a bloodless surgical field and allows the use of smaller venous cannulas and reduced $\mathrm{CPB}$ circuit volumes. The arterial pump acts as an artificial heart by drawing blood from this reservoir and propelling it through a heat exchanger, an artificial lung (oxygenator or gas exchanger) and, finally, an arterial line filter [15]. The blood is then returned to the patient through an arterial cannula positioned in the ascending aorta or other major artery. Additional cardiopulmonary bypass pumps or other components are employed as needed to suck blood from the surgical field, provide cardioplegia solution to produce cardiac electromechanical silence, decompress the heart through a vent and remove fluid (ultrafiltration) $[9,16]$. Thus, the cardiopulmonary machine temporarily assumes the functions of the heart, lungs and, to a lesser extent, the kidneys [17].

The contact of blood with non-endothelial surfaces of the $\mathrm{CPB}$ circuit induces an intense inflammatory response. This results in platelet activation and initiation of the coagulation cascade with decreased levels of circulating coagulation factors. Endothelial cells and leukocytes are activated, releasing mediators that may contribute to capillary leakage and tissue edema. Many of the challenges encountered during weaning from $\mathrm{CPB}$ and in the postoperative period are considered consequences of this inflammatory sequence [17]. In addition, the $\mathrm{CPB}$ circuit priming solution (typically 1 to 2 liters of a balanced crystalloid solution) results in hemodilution with anemia and temporary or persistent coagulopathy [18].

\section{Protocol}

Surgical procedures that require $\mathrm{CPB}$ follow a predictable sequence of events including $\mathrm{CPB}$ circuit initiation and testing, anticoagulation, vascular cannulation, $\mathrm{CPB}$ initiation and maintenance, and finally $\mathrm{CPB}$ weaning and termination. Myocardial arrest with myocardial protection and myocardial reperfusion are additional considerations when a stationary heart and a bloodless field are desired. Protocols established for the management of CPB parameters approaching normal physiology [19].

- In adults, the target flow rate during CPB is 2.2 to 2.4 Liters / $\mathrm{min} /$ $\mathrm{m}^{2}$ in normothermic patients to approach a normal cardiac index; cardiac index is appropriately decreased if hypothermia is induced $[6,20]$.

- Mean arterial pressure (MAP) is usually directed to $\geq 65 \mathrm{mmHg}$, but the goal may be higher in elderly patients and those with cerebrovascular disease. MAP should not exceed $100 \mathrm{mmHg}$ [20,21].

- The adequacy of target organ perfusion is determined by the analysis of arterial blood gases and mixed venous oxygen saturation (SvO2), which is continuously monitored and maintained $\geq 75$ percent throughout CPB. Arterial blood gas analysis, baseline deficit and lactate levels are intermittently checked (approximately every 30 minutes) [22].

- ECB weaning preparations and checklists to ensure readiness for weaning are described separately $[9,18]$.

\section{Cardiopulmonary Bypass}

Objectives during CPB include maintenance of general anesthesia, anticoagulation, and parameters that approximate normal physiology for optimal end-organ function [23]. Arterial oxygenation, ventilation and blood gas - Arterial pO 2 is maintained at 150 to $250 \mathrm{mmHg}$ during $\mathrm{CPB}$. A continuous arterial blood pressure monitoring system is located on the arterial line of the $\mathrm{CPB}$ circuit, and a continuous venous oximeter is located on the venous return line. Arterial blood gas values are checked in the laboratory or by point-of-care testing approximately every 30 minutes, which also allows intermittent recalibration of the continuous blood gas monitor in the arterial line [24]. More specific oxygenation strategies (eg targeting hyperoxia) have not been shown to be clinically beneficial. A 2018 systematic review of 12 randomized trials noted little evidence of differences in the outcome of a hyperoxic rather than normoxic oxygenation strategy used during cardiac surgery, but the studies were small and heterogeneous $[21,22,8]$. Two studies $[9,25]$ reported a reduction in postoperative myocardial enzymes and one study reported a reduction in mechanical ventilation time in normoxic groups. Alpha-stat management of arterial blood gases without temperature correction is used to maintain a normal range for pCO 2 (35 to $45 \mathrm{mmHg}$ [ 4.7 to $6 \mathrm{kPa}$ ]) and $\mathrm{pH}$ (7.35 to 7.45 ) [25]. Maintaining $\mathrm{PaCO} 2$ and $\mathrm{pH}$ within this physiological range during CPB is important to preserve cerebral self-regulation [26].

Ventilation of the lungs during CPB has not been shown to improve lung function and may increase the technical difficulty for the surgeon. Some doctors use continuous positive airway pressure 
(CPAP) during CPB. In a meta-analysis of seven small randomized trials, the use of 5 to $15 \mathrm{cmH} 20 \mathrm{CPAP}$ improved the postoperative alveolar-arterial oxygen gradient (Aa gradient) by a weighted average difference of approximately $31 \mathrm{mmHg}$ [23]. Pump flow and mixed venous oxygen saturation - CPB flow rates are set at 2.2 to 2.4 Liters / min per $\mathrm{m}^{2}$ in a normothermic patient to provide adequate blood flow for optimal brain and other end organ perfusion. . These rates may be slightly decreased if hypothermia is employed [27]. Acute decreases in Mean Arterial Pressure (MAP) or increases in Central Venous Pressure (CVP) may indicate a sharp reduction in venous return due to the surgeon's lifting of the heart (causing a reduction in flow), a misplaced or twisted arterial or venous cannula, or obstruction of blood flow by an air blockage. With severe reduction in venous return, the perfusionist may need to administer volume to the $\mathrm{CPB}$ reservoir or reduce arterial flow. Persistent reductions in arterial line flow and / or venous return should be urgently addressed, identifying and correcting the cause $[2,5,24]$

Mixed venous oxygen saturation ( $\mathrm{SvO} 2$ ) is maintained $\geq 75 \%$ throughout $\mathrm{CPB}$ as a peripheral perfusion adequacy monitor. Persistent SvO 2 values $<75 \%$ may indicate inadequate oxygen supply and are associated with worse outcomes, including postoperative delirium and decreased long-term survival [27]. In addition, lactate and baseline deficit values are measured when arterial blood gases are obtained approximately every 30 minutes. Although absolute lactate values are multifactorial, increasing levels during CPB represent anaerobic metabolism at the cellular level due to inadequate tissue oxygen delivery and may reflect hypoperfusion during $\mathrm{CPB}$, particularly if maintained or associated with low mixed venous saturation. oxygen (SvO $2<70 \%$ ) [28]. Treatment for SvO $2<75$ percent, baseline deficit less than -5 , or lactate level $>4 \mathrm{mEq} / \mathrm{L}$ is directed to increasing $\mathrm{CPB}$ flow rate as well as ensuring that blood gas and hemoglobin levels ( $\mathrm{Hgb}$ ) are suitable. It is common practice to administer sodium bicarbonate for a baseline deficit below -5 , or lactate level $>4 \mathrm{mEq} /$ Liter, but excessive administration of sodium bicarbonate may cause postoperative hypernatremia $[19,20]$. Although increased lactate level during CPB is more often the result of inadequate tissue perfusion, persistent postoperative lactic acidosis may occur due to other factors (eg, beta-adrenergic metabolic effects of epinephrine infusion) [28]. Mean blood pressure - In the context of acceptable CPB flow rates, MAP is generally directed to $\geq 65 \mathrm{mmHg}$; a higher target may be selected in elderly patients and in those with cerebrovascular disease [28].

In a retrospective study30 of nearly 7500 patients, postoperative stroke was associated with prolonged periods with MAP $<65 \mathrm{mmHg}$, with an adjusted odds ratio (OR) of 1.13 for each 10-minute period that was 55 to $64 \mathrm{mmHg}$ during and after surgery. After CPB (95\% CI $1.05-1.21)$ and adjusted OR of 1.16 for each 10 -minute period when MAP was $<55 \mathrm{mmHg}$ (95\% CI 1.08-1.23) Other factors associated with stroke in this study were advanced age, history of hypertension, combined procedures of valvular myocardial revascularization, prolonged CPB duration, emergency surgery, and new onset of postoperative atrial fibrillation $[11,29]$. However, a randomized study in 197 patients showed no reduction in the number or volume of cerebral infarcts in those who received vasopressor therapy to maintain a nearly physiological MAP target (70 to $80 \mathrm{mmHg}$ ) compared to those who had a smaller target. MAP (40 to $50 \mathrm{mmHg}$ ) [30]. Episodes of low or high blood pressure during CPB have been associated with the risk of brain events and other adverse outcomes, although a causal relationship has not been established [21]. A retrospective study [31] observed that impaired cerebral self-regulation is common, occurring in almost one third of patients undergoing cardiac surgery with CPB. In this study, impaired self-regulation was associated with small brain vessel disease (identified with brain magnetic resonance imaging) but was not associated with large vessel disease (identified by transcranial Doppler). However, it is not yet clear how these data inform the management of blood pressure in individual patients.

During attempts to increase MAP, it is important to ensure adequate pump flow and to maintain clear communication between the anesthesiologist (who may be adjusting the systemic vascular resistance of the vasopressor patient) and the perfusionist (who may be adjusting the flow rate) effective heart rate with changes in pump flow) [34]. MAP should not exceed $100 \mathrm{mmHg}$, in most patients a range of MAP from 65 to $100 \mathrm{mmHg}$ allows for self-regulation of cerebral circulation and other target organs throughout $\mathrm{CPB}$, although it is not possible to determine an accurate range of self-regulation for each patient. Individual $[3,25]$.

\section{Hypotension}

Moderate hypotension - In the context of acceptable CPB flow rates, if MAP is below the target range, the perfusionist may increase pump flow (equivalent to increasing cardiac output), particularly if $<2.4 \mathrm{~L} / \mathrm{min} / \mathrm{m}^{2}$. If hypotension persists after increased pump flow, a vasopressor may be administered as an intravenous (IV) bolus or by continuous infusion. In many institutions, small bolus doses of phenylephrine (eg 40 to $100 \mathrm{mcg}$ ) are administered directly into the $\mathrm{CPB}$ reservoir to treat hypotension. Phenylephrine infusions at 10 to $200 \mathrm{mcg} / \mathrm{min}$, vasopressin at 0.04 units / $\mathrm{min}$ or norepinephrine at 0.02 to $0.06 \mathrm{mcg} / \mathrm{kg} / \mathrm{min}$ are also commonly employed [22]. Severe vasoplegia - systemic vasodilation, characterized by markedly decreased systemic vascular resistance (SVR) and low MAP during and after $\mathrm{CPB}$, occurs in 5 to 25 percent of patients undergoing cardiac surgery. Risk factors include the preoperative use of agents such as angiotensin converting enzyme (ACE) inhibitors, heparin or calcium channel blockers, as well as hemodynamic instability before passage [17]. Before treating low blood pressure near the end of the $\mathrm{CPB}$ period, it is important to verify that radial blood pressure is not markedly underestimating central aortic pressure. A significant central pressure gradient associated with end-CPB rewarming is often present during cardiac surgery. Attaching a pressure transducer to the side port of the aortic cannula after CPB is complete, or the use of a surgeon-inserted femoral intraarterial catheter in the field will usually provide an accurate estimate of true central aortic pressure [33].

If hypotension due to vasoplegia (low SVR) is confirmed, a continuous vasopressor infusion is usually necessary. Although an optimal approach for vasopressor selection during $\mathrm{CPB}$ has not been established, observations in the distributive shock scenario 
suggest that administration of vasopressin or a combination of vasopressin with noradrenaline or phenylephrine is associated with lower atrial fibrillation rates compared to administration. isolated from norepinephrine [34]. If these agents are ineffective, methylene blue 1 to $2 \mathrm{mg} / \mathrm{kg}$ IV for 20 minutes may be administered to reduce the responsiveness of nitric oxide resistance vessels. Notably, methylene blue should be avoided in patients receiving chronic serotonin therapy (eg, fluoxetine) because of the risk of serotonin syndrome and may interfere with monitors employing oximetry to measure oxygen saturation (pulse oximetry and cerebral oximetry) [5,29]. Hypertension - If MAP increases to $>90 \mathrm{mmHg}$ during $\mathrm{CPB}$, treatment includes increasing the concentration of volatile anesthetic administered through the $\mathrm{CPB}$ circuit and / or administering additional IV anesthetic. Occasionally, administration of a vasodilator may be required. For brief periods, pump flow may be reduced while these pharmacological interventions are effective [35]. Anticoagulation Maintenance - The adequacy of heparin anticoagulation is measured with point-of-care tests such as activated whole blood clotting time (ACT) every 30 minutes to maintain a target value during CPB (typically above 480 seconds). If available, plasma heparin concentrations may also be determined by treatment point assays such as Hepcon with target heparin concentration $\geq 4$ units / $\mathrm{mL}$. Protocols in some institutions emphasize the treatment of heparin concentrations $<4$ units / $\mathrm{mL}$, even if ACT values are adequate [36].

\section{Special Population Management}

Specific management strategies are employed during CPB for patients with aortic insufficiency, cerebrovascular disease, renal failure, or vasoplegia and for those undergoing a period of elective deep hypothermic circulatory arrest (DHCA) [6,30]. Pre - existing Aortic Regurgitation (AR) can be diagnosed and its severity characterized by intraoperative Transesophageal Echocardiography (TEE) examination in the pre - reception period. During $\mathrm{CPB}$, the presence of AR may limit the effectiveness of administration of anterograde cardioplegia solution to the coronary artery ostia after the ascending aorta is crossed [37]. Much of the cardioplegia solution will regurgitate through the incompetent aortic valve to the Left Ventricle (LV). The severity of RA can be influenced by the increased aortic root pressure that occurs during attempted delivery of anterograde cardioplegia and surgical manipulations that further distort the normal aortic root and valve geometry [38]. In addition, cardioplegia solution that flows back through the incompetent aortic valve may cause LV distention as the ventricle is not ejecting regularly due to bradycardia, asystole or ventricular fibrillation. Distension causes increased LV wall tension. In combination with inadequate coronary delivery of anterograde cardioplegia solution, this may result in inadequate myocardial protection and severe LV dysfunction. In this situation, a LV ventilator is placed by the surgeon to keep the ventricle in an uncompressed state $[4,15,28]$.

Correct ventilation placement and effective LV decompression are confirmed with the TEE examination. Subsequently, continuous monitoring of TEE and Pulmonary Artery Pressure (PAP) supplement the surgical detection of a displaced LV output or recurrence of LV distension [28]. If the administration of anterograde cardioplegia is inadequate due to RA, the cardiac surgeon usually minimizes the attempted delivery by this route, opting for retrograde cardioplegia provided by the coronary sinus. In selected aortic valve or aortic root procedures, it may be necessary to implant cardioplegia solution directly into the coronary ostia after aortic clamping and opening of the aortic root [36]. Rapid and severe LV distension may occur in a patient with significant RA, even before aortic clamping, if ventricular fibrillation occurs at the onset of $\mathrm{CPB}$ and on cooling. In this situation, the $\mathrm{CPB}$ flow rate may be temporarily reduced to allow the surgeon to manually decompress the $\mathrm{LV}$, since defibrillation is more likely if the heart is empty (not distended). Defibrillation is performed with internal paddles applied directly to the heart to provide 10 to 20 joules of electricity. Subsequently, if LV distension recurs after the application of aortic cross forceps, a left ventricular opening may be inserted [39].

Cerebrovascular disease is common in patients undergoing cardiac surgery. A study that used preoperative magnetic resonance imaging observed a major brain vessel disease in $25 \%$ and small vessel disease present in $35 \%$ of 346 patients undergoing cardiac surgery with CPB. Considerations for patients with known cerebrovascular disease and / or evidence of severe aortic atherosclerosis include maintaining a higher mean arterial pressure than patients without these comorbidities, with careful attention to maintaining hemoglobin $(\mathrm{Hb})$ and hematocrit (Hct) levels. and the prevention of cerebral hyperthermia. The use of intraoperative oximetry and the maintenance of regional cerebral oxygen saturation ( $\mathrm{rSO} 2$ ) in $20 \%$ of baseline values has been advocated by patients at high risk of adverse neurological outcomes, including those with known cerebrovascular disease $[23,39]$.

\section{Conclusion}

Cardiopulmonary Bypass (CPB) is a form in which the patient's blood is diverted from the heart and lungs out of the body. Normal physiological functions of the heart and lungs, including blood circulation, oxygenation, and ventilation, are temporarily taken over by the CPB machine. Most studies do not show a significant increase in the morbidity and mortality of $\mathrm{CPB}$ cardiac surgery in cancer patients, even at an active stage, compared to the normal population. It appears that the survival of cancer patients undergoing cardiac surgery is more related to tumor progression than to the surgical procedure. Medium-term survival is acceptable, although less in active cancer patients at the time of intervention and in those $<2$ years between cancer diagnosis and surgery. Readmission rates are higher than in the general population and are mainly due to the need for cancer treatment and / or complications arising from it. Typical parameters during CPB in adults include controlled flow rate of 2.2 to 2.4 Liters $/ \mathrm{min} / \mathrm{m}^{2}$, maintenance of mean arterial pressure (MAP) $\geq 65 \mathrm{mmHg}$ and mixed venous oxygen saturation $\geq 75 \%$. Maintaining renal blood flow is achieved by maintaining adequate $\mathrm{CPB}$ pump flow throughout $\mathrm{CPB}$ to minimize the risk of Acute Kidney Injury (AKI). Inadequate anesthetic depth is treated by increasing the volatile anesthetic concentration administered by the CPB circuit or by the administration of additional Intravenous (IV) anesthetic agents. It is reasonable to monitor processed EEG indices 
(eg bispectral index) or unprocessed EEG to provide data that may detect inadequate anesthesia during $\mathrm{CPB}$. Decreasing the dose of the selected Neuromuscular Blocking Agent (NMBA) may be adequate during the hypothermic $\mathrm{CPB}$ period; however, additional NMBA is usually required during reheat. Individual assessment of each case should consider both the tumor stage and the chances of complete remission (even in active cancers) before discounting cardiac surgery. Larger studies are needed to allow comparison of morbidity and mortality outcomes and survival with and without CPB to identify their influence on these variables and long-term recurrence.

\section{References}

1. Knapik P, Nadziakiewicz P, Urbanska E, Saucha W, Herdynska M, et al. (2009) A circulação extracorpórea aumenta a glicemia pós-operatória e o consumo de insulina após cirurgia coronariana. Ann ThoracSurg 87: 1859-1865.

2. Kaya K, Cavolli R, Telli A, MF Soyal, Aslan A, (2010) Cirurgia de revascularização miocárdica com circulação extracorpórea com circulação extracorpórea na síndrome coronariana aguda: uma análise clínica. J CardiothoracSurg.

3. Mistiaen WP, van Cauwelaert P, Muylaert P Wuyts F, Harrison F Bortier H (2004) Efeito de malignidade prévia na sobrevivência após cirurgia cardíaca. Ann ThoracSurg 77: 1593-1597.

4. Musleh GS, Patel NC, Grayson AD, Pullan DM, Keenan DJ, et al. (2003) A cirurgia de revascularização do miocárdio sem circulação extracorpórea não reduz as complicações gastrointestinais. Eur J CardiothoracSurg 23: 170-174.

5. Nurözler F, Kutlu T, Kücük G (2006) Bypass coronário sem circulação extracorpórea para pacientes com neoplasia concomitante. Circ J 70: 1048-1051.

6. Pivoto FL, Lunardi Filho WD, Santos SS, Almeida MA, da Silveira RS (2010) Diagnósticos de enfermagem em pacientes no pós-operatório de cirurgia cardíaca. Acta Paul Enferm 23: 665-670.

7. Woods SL, Froelicher ES, Motzer SU (2005) Enfermagem em cardiologia. 4a ed. São Paulo; Barueri (SP): Manole.

8. Barry AE, Chaney MA, Londres MJ (2015) Manejo anestésico durante a circulação extracorpórea: uma revisão sistemática. AnesthAnalg 120: 749.

9. Warren OJ, Smith AJ, Alexiou C, (2009) Resposta inflamatória à circulação extracorpórea: parte 1 - mecanismos da patogênese. J CardiothoracVascAnesth 23 : 223.

10. Wan S, LeClerc JL, Vincent JL (1997) Resposta inflamatória à circulação extracorpórea: mecanismos envolvidos e possíveis estratégias terapêuticas. Peito 112: 676.

11. Dia JR, Taylor KM (2005) Síndrome da resposta inflamatória sistêmica e circulação extracorpórea. Int J Surg 3: 129.

12. Warren OJ, Watret AL, de Wit KL (2009) A resposta inflamatória à circulação extracorpórea: parte 2 - estratégias terapêuticas antiinflamatórias. $J$ CardiothoracVascAnesth 23: 384.

13. Murphy GS, Hessel EA $2^{\circ}$, Noivo RC (2009) Perfusão ideal durante o bypass cardiopulmonar: uma abordagem baseada em evidências. AnesthAnalg 108: 1394

14. Hogue Jr CW, Palin CA, Arrowsmith JE (2006) Manejo do bypass cardiopulmonar e desfechos neurológicos: uma avaliação baseada em evidências das práticas atuais. AnesthAnalg 103: 21.

15. Joshi B, Ono M, Brown C (2012) Prever os limites da autorregulação cerebral durante o bypass cardiopulmonar. AnesthAnalg 114: 503.

16. Shann KG, Likosky DS, Murkin JM, et al. (2006) Uma revisão baseada em evidências da prática de circulação extracorpórea em adultos: um foco na lesão neurológica, controle glicêmico, hemodiluição e resposta inflamatória. $J$ ThoracCardiovascSurg 132: 283.

17. Heinrichs J, Lodewyks C, Neilson C (2018) O impacto da hiperóxia nos resultados após cirurgia cardíaca: uma revisão sistemática e síntese narrativa. Pode J Anaesth 65: 923.

18. Murkin JM, Martzke JS, Buchan AM, et al (1995) Estudo randomizado da influência da técnica de perfusão e da estratégia de manejo do $\mathrm{pH}$ em 316 pacientes submetidos à cirurgia de revascularização do miocárdio. II. Resultados neurológicos e cognitivos. J ThoracCardiovascSurg 110: 349.

19. Reis Miranda D, Gommers D, Struijs A, et al. (2004) O conceito de pulmão aberto: efeitos sobre a pós-carga ventricular direita após cirurgia cardíaca. Br J Anaesth 93: 327.

20. Bignami E, Guarnieri M, Saglietti F (2016) Ventilação mecânica durante o bypass cardiopulmonar. J CardiothoracVascAnesth 30: 1668

21. Svenmarker S, Haggmark S, Östman M, et al. (2013) A saturação venosa central de oxigênio durante a circulação extracorpórea prediz uma sobrevida em três anos. Interact CardiovascThoracSurg 16:21.
22. Wang YC, Huang CH, Tu YK (2018) Efeitos da pressão positiva nas vias aéreas e ventilação mecânica dos pulmões durante a circulação extracorpórea em eventos adversos pulmonares após cirurgia cardíaca: uma revisão sistemática e metaanálise. J CardiothoracVascAnesth 32: 748.

23. Andersen LW (2017) Elevação de lactato durante e após a cirurgia cardíaca em adultos: uma revisão de etiologia, valor prognóstico e gerenciamento. AnesthAnalg 125: 743 .

24. Smulter N, Lingehall HC, Gustafson Y, et al. (2018) Distúrbios no equilíbrio de oxigênio durante o bypass cardiopulmonar: um fator de risco para o delirium pósoperatório. J CardiothoracVascAnesth 32: 684.

25. Smulter N, Lingehall HC, Gustafson Y, et al. (2018) Distúrbios no equilíbrio de oxigênio durante o bypass cardiopulmonar: um fator de risco para o delirium pósoperatório. J CardiothoracVascAnesth 32: 684.

26. Ghadimi K, Gutsche JT, Ramakrishna H, et al. (2016) Uso de bicarbonato de sódio e risco de hipernatremia em pacientes cirúrgicos da aorta torácica com acidose metabólica após parada circulatória hipotérmica profunda. Ann CardAnaesth 19: 454.

27. Ghadimi K, Gutsche JT, Ramakrishna H, et al. (2016) Uso de bicarbonato de sódio e risco de hipernatremia em pacientes cirúrgicos da aorta torácica com acidose metabólica após parada circulatória hipotérmica profunda. Ann CardAnaesth 19: 454.

28. Totaro RJ, Raper RF (1997) Acidose láctica induzida por epinefrina após circulação extracorpórea. CritCareMed 25: 1693.

29. Ono M, Brady K, Easley RB (2014) A duração e a magnitude da pressão arterial abaixo do limiar de autorregulação cerebral durante a circulação extracorpórea estão associadas à maior morbidade e à mortalidade operatória. J ThoracCardiovascSurg 147: 483.

30. Hori D, Brown C, Ono M, etai. (2014) A pressão arterial acima do limite superior da autorregulação cerebral durante a circulação extracorpórea está associada ao delírio pós-operatório. Br J Anaesth 113: 1009.

31. Nomura Y, Faegle R, Hori D (2018) Vasos pequenos cerebrais, mas não grandes da doença, estão associados com autorregulação cerebral prejudicada durante o bypass cardiopulmonar: um estudo de coorte retrospectivo. AnesthAnalg 127: 1314.

32. Fischer GW, Levin MA (2010) Vasoplegia durante cirurgia cardíaca: conceitos e gestão atuais. SeminThoracCardiovascSurg 22: 140.

33. Mekontso-Dessap A, Houël R, Soustelle C (2001) Fatores de risco para vasoplegia pós-circulação extracorpórea em pacientes com função ventricular esquerda preservada. Ann ThoracSurg 71: 1428.

34. Shaefi S, Mittel A, Klick J, et al. (2018) Vasoplegia Após Procedimentos Cardiovasculares - Fisiopatologia e Terapia Direcionada. J CardiothoracVascAnesth 32: 1013 .

35. Stern DH, Gerson JI, Allen FB, Parker FB (1985) Podemos confiar na pressão arterial radial direta imediatamente após o bypass cardiopulmonar? Anestesiologia 62: 557.

36. Bazaral MG, Nacht A, Petre J, et al. (1988) Pressões da artéria radial em comparação com a pressão da artéria subclávia durante a cirurgia da artéria coronária. CleveClin JMed 55: 448.

37. Bazaral MG, Welch M, Golding LA, Badhwar K (1990) Comparação da monitorização da pressão arterial braquial e radial em pacientes submetidos à cirurgia de revascularização miocárdica. Anestesiologia 73:38

38. Denault AY, Tardif JC, Mazer CD, et al. (2012) Separação difícil e complexa da circulação extracorpórea em pacientes cirúrgicos cardíacos de alto risco: um estudo multicêntrico. J CardiothoracVascAnesth 26: 608 .

39. Hajjar LA, Vincent JL, Barbosa Gomes Galas FR, et al. (2017) Vasopressina versus noradrenalina em pacientes com choque vasoplégico após cirurgia cardíaca: o ensaio clínico randomizado VANCS. Anestesiologia 126: 85.

40. Sun LY, Chung AM, Farkouh ME, et al. (2018) Definindo um limiar de hipotensão intraoperatória em associação com acidente vascular cerebral em cirurgia cardíaca. Anestesiologia 129: 440.

41. Vedel AG, Holmgaard F, Rasmussen LS, etai. (2018) Alta Alvo versus o Controle da Pressão Arterial com Alvos Baixos durante a Derivação Cardiopulmonar para Prevenção de Lesão Cerebral em Pacientes com Cirurgia Cardíaca: Um Ensaio Controlado Aleatório. Circulação 137: 1770.

42. Omar S, Zedan A, Nugent K. (2015) Síndrome da vasoplegia cardíaca: fisiopatologia, fatores de risco e tratamento. Am J MedSci 349: 80.

\section{Citation:}

Edmo Atique Gabriel, Camila Alcalde Mazza and Marina Alves Jacintho de Mello (2020) Splenic Changes in Heart Surgery with Circular Circulation. J Cardiol Clin Pract, Volume 3(1): 1-5. 